\title{
DISCIPLINARY SANCTIONS APLICCABLE TO ROMANIAN CIVIL SERVANTS
}

\author{
A.N. Puran, L. Olah
}

\author{
Andra Nicoleta Puran \\ Faculty of Law and Administrative Sciences, Department of Law and Administrative \\ Sciences, University of Piteşti, Piteşti, Romania \\ *Correspondence: Andra-Nicoleta Puran, University of Piteşti, 1 Târgul din Vale Street, \\ Piteşti, Romania \\ E-mail: andradascalu@yahoo.com

\section{Lavinia Olah} \\ Faculty of Law and Administrative Sciences, Department of Law and Administrative \\ Sciences, University of Piteşti, Piteşti, Romania \\ *Correspondence: Lavinia Olah, University of Piteşti, 1 Târgul din Vale Street, Piteşti, \\ Romania \\ E-mail: lavinia olah@yahoo,com
}

\begin{abstract}
Disciplinary liability of civil servants, as form of judicial liability, has started a series of debates among Romanian doctrinaires. This paper aims to analyze the disciplinary sanctions applicable to civil servants subjected to Law No 188/1999, starting from the analysis of the concept of civil servant and from their classification according to the doctrine and legal provisions.
\end{abstract}

Keywords: civil servant, disciplinary offence, disciplinary sanction

\section{Introduction}

Specific regulations regarding the statute of civil servants are stated by Law No $188 / 1999^{1}$ with its subsequent modifications and amendments.

Law No 188/1999 of the Statute of Civil Servants, states, as any statute of a profession, the conditions of the judicial liability for civil servants.

The specificity of the disciplinary liability of civil servants is given by the actions representing disciplinary offences, by the specific sanctions and by their own disciplinary procedure.

Given that the disciplinary liability of civil servants is a very broad topic, we shall analyze, without aiming to deplete the subject, the disciplinary sanctions applicable for the disciplinary offences committed by them.

\section{Section 1. General aspects regarding civil servants}

The definition of the profession and of the civil servant has known numerous attempts in the doctrine and started so many controversies ${ }^{2}$.

It was correctly mentioned ${ }^{3}$ that the civil position and the civil servant are legal institutions of the public law, in general, and especially of the administrative law, over which

\footnotetext{
${ }^{1}$ Published in the Official Gazette No 600/8 December 1999, republished in the Official Gazette

${ }^{2}$ In order to analyze the doctrinaire controversies on the legal status of civil servants see Verginia Vedinaş, Drept administrativ, $7^{\text {th }}$ edition reviewed and added, Universul Juridic Publishing House, Bucharest, 2012, pp. 501-504
} 
doctrinaire, legislative and jurisprudential controversies have arisen in time, both in literature, as well as in the practice of different European states ${ }^{4}$ having an administrative system well shaped, but also in the Romanian legislation and jurisprudence.

A theory ${ }^{5}$ mentioned, that, actually, the public servant is nothing else but an employee with a special statute, his job report representing "a typical form of a legal employment report, which, though different from the individual employment contract is not entirely different from the latter one..." This theory has had its opponents ${ }^{6}$, to which we concur, who showed that the institution of civil servants is not included in the labor law, being part of the public law, especially of the administrative law, "the undeniable specificity of the job report of the civil servant towards the job report of an employee".

Art 2 of the Law No 188/1999 defines both the civil position, as well as the civil servant. Thus, "the civil position represents the entirety of duties and responsibilities settled by the law, in view of fulfilling the prerogatives of public power by the central public administration, by the local public administration and by the autonomous administrative authorities". The "civil servant is the person nominated, as per the law, in a public position. The person who was released of the public position and it is now in the reserve body of civil servants preserves the quality of civil servant".

The doctrine ${ }^{7}$ defines the civil position as "the determined legal situation of the natural person having the prerogatives of a public authority, as a public power, aiming the continuous achievement of a public interest". Another opinion ${ }^{8}$ states that the civil position represents "the entirety of the rights and obligations established for a natural person (chosen or appointed) in order to achieve the competence of a public authority, public institution or agency, for the continuous fulfillment of a public interest".

The civil servant is defined as the "person invested by appointment in a public position as part of a public administrative service, with the purpose of achieving its competence" ${ }^{\prime 9}$ or "the natural person chosen or appointed in a public position as part of a public authority or institution, with the purpose of fulfilling their competences and prerogatives"10. The law establishes for the civil servant the coordinates of his position, his attributions being general, in the best interest of the public service, his legal situation being objective and, as a consequence, the relation between the civil servant and civil position being an objective legal report, the civil servant exerting a legal power ${ }^{11}$.

The statute of the civil servants defines another important institution, namely the body of the civil servants representing the entirety of civil servants within the autonomous administrative authorities and within authorities and bodies from central and local public administration $^{12}$. It was stated ${ }^{13}$ that the performance of the prerogatives of public power "has

\footnotetext{
3 Andreea Drăghici, Ramona Duminică, Deontologia funcționarului public. Curs pentru studenții programului frecvență redusă, University of Piteşti Publishing House, Piteşti, 2010, p.8

${ }^{4}$ See also Elise Nicoleta Vâlcu- Introducere în dreptul comunitar material, Sitech Publishing House, Craiova, 2010, pp.106 and next.

${ }^{5}$ Ş. Beligrădeanu, Considerente - teoretice şi practice - în legătură cu Legea nr. 188/1999 privind Statutul funcționarilor publici, in Law Review No 2/2010, p.7.

${ }^{6}$ Verginia Vedinaş, Despre natura juridică a raportului de serviciu al funcționarilor publici, in the Private Law Review No 5/2010, pp.190-207.

${ }^{7}$ Verginia Vedinaş, Drept administrativ, 7th edition reviewed and added, Universul Juridic Publishing House, Bucharest, 2012, p. 506.

${ }^{8}$ Doina Popescu, Andreea Drăghici, Deontologia funcționarului public, Paralela 45 Publishing House, Piteşti, 2005, p. 13.

${ }^{9}$ Verginia Vedinaş, Drept administrativ, 7th edition reviewed and added, Universul Juridic Publishing House, Bucharest, 2012, p. 507.

${ }^{10}$ Andreea Drăghici, Ramona Duminică, Deontologia funcționarului public. Curs pentru studenții programului frecvență redusă, University of Piteşti Publishing House, Piteşti, 2010, p. 18.

${ }_{11}^{11}$ Dana Apostol Tofan, Drept administrativ, 1st Volume, All Beck Publishing House, Bucharest, 2003, p. 283.

${ }^{12}$ Art 2 Para 5 of the Law No 188/1999 with its subsequent modifications and amendments.
} 
the credit of motivating every person to aspire to the quality as civil servant, knowing that the civil servants are a prestigious socio-professional category...".

The Law No 188/1999 classifies the civil servants as such:

A. Debutant andpermanents civil servants (Art 11 of the Statute)

Can be appointed as debutant civil servants the persons who promoted the evaluation for a public position and do not fulfill the conditions previewed by law for a permanent one. Can be appointed as permanent civil servants:

a) the debutant civil servants who finalized the probation period previewed by the law and who obtained an appropriate result at the evaluation;

b) the persons who enter the civil servant body through contest and who have the experience required for occupying the public position of minimum 12 months, 8 months and, respectively, 6 months, depending on the level of concluded studies;

c) the persons who promoted training programs in public administration.

B. 1. High ranking civil servants (Art 12 of the Statute):

a) General Secretary of the Government and deputy to general secretary of the Government;

b) General Secretary from the ministries and from other specialized entities of the central public administration;

c) Prefect;

d) Deputy to general secretary from the ministries and from other specialized entities of the central public administration;

e) Sub-prefect;

f) Government inspector.

2. Managing civil servants (Art 13 of the Statute):

a) General Director and deputy to general director within the structure of autonomous administrative authorities, of ministries and of the other specialized bodies of the central public administration, as in the specific public positions assimilated to those;

b)Director and deputy to director within the structure of autonomous administrative authorities, within ministries and within the other specialized units of the central public administration, and in the specific public positions assimilated to those;

c) Secretary of the administrative - territorial unit;

d) executive director and deputy to executive director of disconcerted public services of ministries and of the other specialized bodies of the central public administration from the administrative - territorial units, within the prefecture, within the structures of the authorities of the local public administration and of their subordinated bodies, as in the specific public positions assimilated to those;

e) Head of service, as in the specific public positions assimilated to this;

f) Head of office, as in the specific public positions assimilated to this.

3. Execution civil servants (Art 14 of the Statute):

a) Execution civil servants of first class: councilman, juridical councilman, auditor, expert, inspector, as in the specific assimilated public positions;

b) Execution civil servants of second class: specialty referent and the public positions assimilated to this;

c) Execution civil servants of third class: referent and the public positions assimilated to this.

According to Art 77 of the Statute, the disciplinary responsibility of the civil servants is engaged if they perform actions representing disciplinary deviations. The disciplinary deviation, as the only ground of the disciplinary responsibility, is defined by the same article and represents "the infringement by fault of the duties appropriate to the public position held by the civil servants and of the rules of professional and civil behavior regulated by norms".

\footnotetext{
${ }^{13}$ Alina Livia Nicu, Statutul funcționarului public între plus şi minus, Universitaria Publishing House, Craiova, 2007, p. 29.
} 
The Statute not only defines the disciplinary deviation committed by civil servants, but also states, limitative, in order to avoid the abuses committed by superiors, the actions representing such deviation:

a) Systematic delay in performing duties;

b) repeated negligence in solving duties;

c) Unmotivated absences from work;

d) repeated disrespect of working hours;

e) Interventions or persistence in solving various requests outside the legal frame;

f) Disrespect of the professional secrete or of the confidentiality of secret works;

g) Events harming the prestige of the public authority or body;

h) Performing political nature activities during the working hours;

i) Refusal to fulfill duties;

j) Infringement of legal provisions referring to duties, incompatibilities, interest conflicts and interdictions set by law for the civil servants;

k) Other acts considered disciplinary deviations in the norms from the field of public position and civil servants.

Art 23 Para 1 of the Law No $7 / 2004^{14}$ on the Code of Conduct for the Civil Servants states that for the infringement of the provisions previewed by this Code the civil servant is held disciplinary responsible.

\section{Section 2. Specific sanctions}

All the disciplinary sanctions applicable for civil servants are stated by Art 77 Para 3 of the Statute:

a) Written reprimand;

b) Reduction of salary rights with up to $5-20 \%$ for a period up to 3 months;

c) Suspension of the advancement right in salary levels or, as it case may be, of the advancement right in public position for a period that goes from 1 to 3 years;

d) Degradation in salary levels or degradation in public position for a period up to one year;

e) Removal from the public position.

It was stated in the doctrine ${ }^{15}$ that it has been eliminated from the actual form of the Statute one of the disciplinary sanctions having a preponderant moral feature, namely the warning, considering that previous to this modification, the same author has criticized the existence of two moral disciplinary sanctions.

a) Written reprimand has been defined by the doctrine as being the "written warning of the civil servant regarding the seriousness of his deviation having negative or detrimental consequences for the public structure's or authority's activity with the express mention that on the future he shall be subjected to more severe sanctions, going up to his dismissal"16.

Written reprimand is the only sanction applicable to civil servants having a preponderant moral feature, being usually applied for the commission of a first disciplinary deviation, which did not caused significant prejudices.

b) Reduction of salary rights with up to 5-20\% for a period up to 3 months is a disciplinary sanction with a predominantly patrimonial feature.

The legislator has foreseen for this sanction two categories of limits: one regarding the quantum of the salary reduction and one regarding the period for which this sanction can be sentenced.

\footnotetext{
${ }^{14}$ Published in the Official Gazette of Romania, Part 1, No 157/23 February 2004 and republished based on Art II of the Law No 50/2007 for the modification and amendment of Law No 7/2004 on the Code of Conduct for the Civil Servants, published in the Official Gazette of Romania, Part 1, No 194/21 March 2007, renumbering the texts

${ }^{15}$ Verginia Vedinaş, Statutul funcționarilor publici, Universul Juridic Publishing House, Bucharest, 2009, p. 291.

${ }^{16}$ I. Santai, Drept administrativ şi ştiința administrației, Risoprint Publishing House, Cluj-Napoca, 2008, p. 137.
} 
Regarding the quantum of salary reduction, have been stated two limits: one inferior of $5 \%$ under which it cannot be descended, and one superior which cannot exceed $20 \%$. Unlike the common law, where the similar sanction affects only the base salary, for the civil servants the diminution affects all salary rights.

The measure cannot be disposed for over 3 months, without specifying its minimum period. As lege ferenda, we consider that the provisions regarding this sanction should be completed; both for the protection of the civil servants who are generally sanctioned with the maximum period, as well as for the achievement of the purpose aimed by this disciplinary measure, in the actual regulation being applied even for a single day.

c) Suspension of the advancement right in salary levels or, as it case may be, of the advancement right in public position for a period that goes from 1 to 3 years is considered in the doctrine ${ }^{17}$ as being a sanction specific for the civil servants.

It is considered ${ }^{18}$ that this sanction is applicable to those civil servants who, having a history of disciplinary deviations, commit a serious deviation causing outstanding damages for the public institution or authority.

This sanction can be sentenced for minimum 1 year but without exceeding the maximum of 3 years.

d) Degradation in public position for a period up to one year is a sanction affecting the civil servant both pecuniary as well as morally.

The degradation in public position assumes the diminution of the salary rights. This sanction cannot be sentenced for more than one year, the minimum period being unlimited.

The mandatory degradation in a public position and not in an auxiliary one is obvious from the legal provision.

e) Removal from the public position is the most serious sanction applicable for civil servants, being equivalent with the disciplinary dissolution of the contract in the common law.

This is the only offence applicable for civil servants for which the Law No 188/1999 states the deviations for which is applicable. Thus, Art 101 states that the removal from public position can be sentenced only in the following cases:

a) for repeated commitment of various disciplinary deviations or of a disciplinary deviation with serious consequences;

b) if a legal reason of incompatibility has arisen, and the civil servant doesn't take steps to remove it within 10 calendar days since the date of intervention of the incompatibility case.

The civil servant who is disciplinary sanctioned with the removal from the public position shall no longer held another public position for a period stated by Art 82 Para 1 Let c) of the Statute, stated for the radiation of this sanction, namely 7 years ${ }^{19}$. $\operatorname{aspects}^{20}$ :

The individualization of the disciplinary sanction is made according to the following

the seriousness of the offence representing a disciplinary deviation

the circumstances in which it was committed

- the degree of guilt of the civil servant

the general behavior of the civil servant during service

the consequences of the deviation

- the perpetration of other disciplinary deviations by the civil servant which have not been radiated yet. The public authorities and institutions where the civil servants are appointed have the obligation, according to Art 48 Para 3 of the Decision, to request from the former employer of the civil servant his disciplinary situation, within 10 days from the issuance of the administrative act of appointment. The obligation belongs to the public

\footnotetext{
${ }^{17}$ I. Santai, Drept administrativ şi ştiința administrației, Risoprint Publishing House, Cluj-Napoca, 2008, p. 138.

${ }^{18}$. Dabu, Răspunderea juridică a funcționarului public, Global Lex Publishing House, Bucharest, 2000, p.268

${ }^{19}$ Ana Mocanu-Suciu, Deontologia funcției publice, Techno Media Publishing House, Sibiu, 2010, pp.143-144

${ }^{20}$ Stated both by Art 77 Para 4 of the Statute, as well as by Art 47 Para 2 of the Decision.
} 
authorities and institutions only for those civil servants whose employment contracts have stopped with less than three months before their appointment in a public position.

\section{Section 3. Application of sanctions}

The administrative act of sanction is issued within 10 calendar days from the moment when the report of the disciplinary commission is received, by the person who has legal competence in applying the disciplinary sanction. Under the sanction of the absolute void, the administrative act of sanction shall be accompanied by the report of the disciplinary commission and shall mandatory comprise:

a) The description of the offence representing a disciplinary deviation;

b) The legal ground based on which the disciplinary sanction is applied;

c) The reason for which has been applied another sanction than the one proposed by the disciplinary commission, where the person who has legal competence in applying the disciplinary sanction, motivated applies another sanction than the one proposed by the disciplinary commission.

The proposal of the disciplinary commission is not mandatory for the one who has competence in applying disciplinary sanctions, being able to apply a lighter sanction.

d) The term in which the sanction can be appealed;

e) The competent court where the administrative act stating the disciplinary sanction can be appealed.

The administrative act is communicated within maximum 15 calendar days from the moment when the report of the disciplinary commission is received, to the following persons and administrative structures:

a) The departments with attributions in the area of human resources from the public institution or authority which is the employer of the civil servant whose action has been classified as a disciplinary deviation;

b) The disciplinary commission who has drafted and sent the report;

c) The civil servant whose action was classified as a disciplinary deviation;

d) The person who has submitted the intimation.

If by the same intimation are reported several disciplinary deviations committed by the same civil servant, the disciplinary commission shall propose, after the administrative investigation, the application of a single disciplinary sanction, with the consideration of all disciplinary deviations.

The disciplinary competence ${ }^{21}$ in applying the sanctions is stated by Art 78 of the Statute of civil servants.

Thus, the written reprimand can be applied directly by the person with legal competence of appointing in public positions. The other four disciplinary sanctions are applied by the person with legal competence of appointing in public position, at the proposal of the disciplinary commission. Regardless of the applied sanction, the preliminary investigation is mandatory.

The disciplinary sanctions can be applied within maximum one year since the moment when the disciplinary commission has been notified about the disciplinary deviation. This term of prescription must be framed in the general term of prescription of the disciplinary liability, the term of two years since the disciplinary deviation was committed. Thus, even if the sanction has been applied within one year since the notification of the disciplinary commission, but exceeding the general term of two years from the commission of the disciplinary deviation, the administrative act is void. The same thing shall happen in the

\footnotetext{
${ }^{21}$ A detailed analysis of the particular aspects determined by the regulations regarding the competence in the application of disciplinary sanctions has been made by A. Trăilescu in Limitele competenței aplicării sancțiunilor disciplinare prevăzute de Legea nr. 188/1999, in Law Review No 1/2009, pp.92-97. The author shows that the manager of such public authority cannot disciplinary sanction a civil servant if the disciplinary commission proposed the classification of the intimation.
} 
reverse situation, namely if it is fulfilled the general term of two years from the commission of the disciplinary deviation but is not fulfilled the term of one year from the notification of the disciplinary commission, thus violating the principle of celerity.

In this respect, in practice ${ }^{22}$ it has been shown that the two terms are not alternative, being mandatory that the application of the disciplinary sanction must circumscribe both terms, so that the failure to respect either one of them is considered as a vice of illegality.

\section{Conclusions}

Starting from the multiple definitions given by the doctrine to the notion of "civil servant", we could say that the civil servant is a legal institution of the public law, namely of the administrative law, being a simple employee with a special statute. The special statute of the civil servants is stated by Law No 188/1999, also previewing special rules regarding their disciplinary liability.

The disciplinary sanctions which can be sentenced for the disciplinary deviations committed by civil servants are:

a) Written reprimand;

b) Reduction of salary rights with up to $5-20 \%$ for a period up to 3 months;

c) Suspension of the advancement right in salary levels or, as it case may be, of the advancement right in public position for a period that goes from 1 to 3 years;

d) Degradation in salary levels or degradation in public position for a period up to one year;

e) Removal from the public position.

The individualizați on and application of these sanctions are made according to special rules stated by the Statute of the civil servants, which were analyzed in this paper.

\section{Bibliography}

Verginia Vedinaş, Drept administrativ, $7^{\text {th }}$ Edition reviewed and added, "Universul Juridic" Publishing House, Bucharest, 2012;

Ş. Beligrădeanu, Considerente - teoretice şi practice - în legătură cu Legea nr. 188/1999 privind Statutul funcționarilor publici, in Law Review No 2/2010;

Andreea Drăghici, Ramona Duminică, Deontologia funcționarului public. Curs pentru studenții programului frecvență redusăa, "University of Piteşti" Publishing House, Piteşti, 2010;

Ana Mocanu-Suciu, Deontologia funcției publice, "Techno Media" Publishing House, Sibiu, 2010;

Verginia Vedinaş, Despre natura juridică a raportului de serviciu al funcționarilor publici, in the Private Law Review No 5/2010;

A. Trăilescu, Limitele competenței aplicării sancțiunilor disciplinare prevăzute de Legea $n r .188 / 1999$, in Law Review No 1/2009;

Verginia Vedinaş, Statutul funcționarilor publici, "Universul Juridic" Publishing House, Bucharest, 2009;

I. Santai, Drept administrativ şi ştiinţa administrației, "Risoprint" Publishing House, Cluj-Napoca, 2008;

Alina Livia Nicu, Statutul funcționarului public între plus şi minus, "Universitaria" Publishing House, Craiova, 2007;

Doina Popescu, Andreea Drăghici, Deontologia funcționarului public, "Paralela 45" Publishing House, Piteşti, 2005;

Dana Apostol Tofan, Drept administrativ, I ${ }^{\text {st }}$ Volume, All Beck Publishing House, Bucharest, 2003;

\footnotetext{
${ }^{22}$ Decision No 1107/01.03.2012 of the High Court of Cassation and Justice in the Cassation Bulletin No 11/2012
} 
V. Dabu, Răspunderea juridică a funcționarului public, Global Lex Publishing House, Bucharest, 2000;

Decision No 1107/01.03.2012 of the High Court of Cassation and Justice in the Cassation Bulletin No 11/2012;

Law no 7/2004 on the Code of Conduct for the Civil Servants

Law No 188/1999 on the Status of Civil Servants. 